\title{
Pax4 Expression does not Transduce Pancreatic Alpha Cells to Beta Cells
}

\author{
Ling Chen ${ }^{a}$ Jing Zhang ${ }^{b}$ Zhuo Zhang ${ }^{c}$ Yaping Chu ${ }^{a}$ Bing Song ${ }^{a} \quad$ Wang Caid $^{d}$ \\ ${ }^{\mathrm{a} E n d o c r i n o l o g y}$ Department, the First Hospital affiliated to Liaoning Medical University, ${ }^{\mathrm{b}} \mathrm{Geriatric}$ \\ Department, the First Hospital affiliated to Liaoning Medical University, 'Scientific bureau, the First \\ Hospital affiliated to Liaoning Medical University, ${ }^{\mathrm{d} D e p a r t m e n t}$ of Obstetrics and Gynecology, the First \\ Hospital affiliated to Liaoning Medical University, Jinzhou, China
}

\section{Key Words}

Diabetes $•$ Alpha-to-beta cell reprogramming $\bullet$ Pax4 $\bullet$ Beta cells $•$ Alpha cells

\begin{abstract}
Background/Aims: The lack of available beta cells greatly limits the use of beta cell transplantation as a therapy for diabetes. Thus, generation of beta cells from other sources is substantially required. Pax4 has been shown to induce reprograming of alpha cells into beta cells during embryogenesis. Nevertheless, whether expression of Pax4 in adult alpha cells could trigger this alpha-to-beta cell reprogramming is unknown. Methods: Here we generated an adeno-associated virus carrying Pax4 and GFP under a CMV promoter (AAV-Pax4). We used AAV-Pax4 to transduce a mouse alpha cell line in vitro, and to transduce primary alpha cells in diabetic mice. Reprogramming was examined by double immunostaining and by changes in beta cell number. The effects on blood glucose were evaluated by fasting blood glucose and glucose response. Results: In vitro, Pax4 overexpression neither induced insulin expression, nor suppressed glucagon expression in alpha cells. In vivo, Pax4 overexpression failed to increase beta cell number, and did not alter hyperglycemia and glucose response in diabetic mice. Conclusion: Pax4 expression is not sufficient to transduce pancreatic alpha cells into beta cells. Overexpression of Pax4 in alpha cells may not increase functional beta cell number in diabetic patients.

Copyright (C) 2015 S. Karger AG, Basel
\end{abstract}

\section{Introduction}

Regulation of blood glucose concentrations requires an appropriate number of betacells that responds properly and dynamically to the changes in blood glucose levels [1]. Of note, autopsy studies have shown decreases in beta-cell mass by 0 to $65 \%$ in type 2 diabetes (T2D), and by $70-100 \%$ in type 1 diabetes (T1D) [2]. A 50\% decrease in beta-cell mass in

Bing Song,

and Wang Cai,

KARGER 125
Endocrinology Department, the First Hospital affiliated to Liaoning Medical University, 5-2 Renmin Road, Jinzhou 121001, (China) and Department of Obstetrics and Gynecology, the First Hospital affiliated to Liaoning Medical University, 5-2 Renmin Road, Jinzhou 121001, (China), E-Mail songbing15@163.com, E-Mail adacaiw@163.com 
rodent studies could result in impaired insulin secretion and induction of insulin resistance [2]. Recovery of functional beta-cell mass has been shown to be an effective therapy for diabetic patients $[1,2]$.

During embryonic pancreatic development, both beta-cell proliferation and beta-cell neogenesis (generation of new beta cells from pancreatic endocrine progenitor cells that express Neurog3) have been found to contribute to the formation of beta cell mass [3-5]. Nevertheless, beta cell proliferation has been shown to be the predominant contributor to postnatal growth of beta cells [6-12]. Since mature beta cells rarely proliferate [13-18], great efforts have been taken to generate insulin-producing beta cells through gene manipulations.

Recently, embryonic expression of a key beta-cell determining transcription factor Pax4 in endocrine progenitors or newly formed alpha cells has been shown to induce formation of beta cells from alpha cells [19]. Moreover, alpha cells have been shown to transdifferentiate into beta cells either long after an extreme beta-cell ablation [20], or shortly after a harsh treatment like pancreatic duct ligation [21]. Based on these studies, we asked the question whether direct overexpression of Pax4 in alpha cells may initiate the reprogramming of alpha cells into beta cells to regain blood glucose control in diabetic animals.

Here we generated an adeno-associated virus carrying Pax4 and GFP under a CMV promoter (AAV-Pax4). We used AAV-Pax4 to transduce mouse an alpha cell line in vitro, and primary alpha cells in diabetic mice. In vitro, Pax 4 overexpression neither induced insulin expression, nor suppressed glucagon expression in alpha cells. In vivo, Pax4 overexpression failed to increase beta cell number, and did not alter hyperglycemia and glucose response in diabetic mice. Together, we found that Pax4 expression was not sufficient to transduce pancreatic alpha cells into beta cells in mature alpha cells, as it did in embryonic animals. Overexpression of Pax4 in alpha cells may not increase functional beta cells in diabetic patients.

\section{Materials and Methods}

\section{Mouse handling}

All animal experiments were performed according to the USA National Institute of Health Guide for the Care and Use of Laboratory Animals, and the protocols were approved by the Ethics Committee for Experimental Research, Liaoning Medical University. Female C57BL/C mice of 12 weeks of age were purchased from the National Resource Center of Model Mice (Nanjing, China). Mice were housed in Pathogen-free environment. The beta-cell toxin streptozotocin (STZ, Sigma-Aldrich, St. Louis, MO, USA) was injected intraperitoneally at $150 \mathrm{mg} / \mathrm{kg}$ body weight.

\section{Cell line culture}

Mouse aTC is an alpha cell line purchased from ATCC (American Type Culture Collection, Manassas, VA, USA). The aTC cells were cultured in Dulbecco's modified Eagle's medium (DMEM) supplemented with 10\% fetal bovine serum (Invitrogen, Carlsbad, CA, USA) and low glucose.

Generation of AAV vectors

AAV-CMV-Pax4-2A-GFP (simplified as AAV-Pax4) and AAV-GFP were prepared as has been previously described [22-24]. Briefly, we used a pAAV-CMV-GFP plasmid (Clontech, Mountain View, CA, USA), a packaging plasmid carrying the serotype 8 rep and cap genes, and a helper plasmid carrying the adenovirus helper functions (Applied Viromics, LLC. Fremont, CA, USA) in this study. The Pax4 construct was prepared from an E13 mouse embryonic pancreatic cDNA, amplified by PCR. The construct was then subcloned into the pAAV-CMV-GFP vector with a 2A to generate the Pax4 vector. The pAAV-CMV-GFP is used as a control. Sequencing was performed to confirm the correct orientation of the prepared vectors. AAV was prepared by triple transfection of the pAAV-CMV-GFP or pAAV-CMV-Pax4-2A-GFP plasmid, R2C8 (containing AAV2 Rep and AAV8 capsid genes) and plAd5 (containing adenovirus helper genes) into HEK293 cells by Lipofectamine 2000 reagent (Invitrogen). The viruses were purified using $\mathrm{CsCl}$ density centrifugation and then titered by a quantitative densitometric dot-blot assay. 


\section{Cellular Physiology Cell Physiol Biochem 2015;36:1735-1742 \begin{tabular}{l|l|l} 
aOI: 10.1159/000430146 & $\begin{array}{l}\text { O 2015 S. Karger AG, Basel } \\
\text { www.karger.com/cpb }\end{array}$ \\
\hline
\end{tabular} \\ Chen et al.: Pax4 Fails to Transduce Alpha to Beta Cells}

In vitro and in vivo transduction

For cell transduction in vitro, the aTC cells were incubated with AAV at a MOI of 100 for 12 hours. For cell transduction in vivo, $10^{9} \mathrm{AAV}$ in $150 \mu \mathrm{l}$ PBS were infused into the mouse pancreas from the pancreatic duct, as has been described before $[25,26]$.

\section{Immunohistochemistry and immunocytochemistry}

Mouse pancreata were dissected out and fixed with 4\% paraformaldehyde (Sigma-Aldrich) for 6 hours, and then cyro-protected in 30\% sucrose for 24 hours. Frozen samples were then sectioned in $6 \mu \mathrm{m}$. Cultured aTC cells were cytospun in slides. Primary antibodies used in immunohistochemistry are guinea pig polyclonal anti-insulin (1:300) (Abcam, Cambridge, MA, USA), rabbit polyclonal anti-Pax4 (1:100) (Santa Cruz Biotechnology, Dallas, Texas, USA), and mouse monoclonal anti-glucagon (1:500) (Sigma-Aldrich). GFP was detected by direct fluorescence. Secondary antibodies were Cy3-, Cy2- and Cy5- conjugated antibodies for corresponding species (Jackson ImmunoResearch Labs, West Grove, PA, USA).

\section{Quantification of beta cell mass}

The quantification of beta cell mass was done as has been described before [9]. Briefly, the pancreata were weighed and then fixed with 4\% Paraformaldehyde for 6 hours, and then cyro-protected in 30\% sucrose for 24 hours in a way to allow longitudinal sections from tail to head of the pancreas to be obtained. Sections at $150 \mu \mathrm{m}$ intervals from whole pancreas were immunostained for insulin and analysed using NIH Image J software. The relative cross-sectional area of beta cells was determined by quantification of the cross-sectional area occupied by beta cells divided by the cross-sectional area of total tissue. The beta-cell mass per pancreas was estimated as the product of the relative cross-sectional area of beta cells per total tissue and the weight of the pancreas. The beta-cell mass was calculated by examining pancreata from 10 animals for each group.

\section{Physiological assessments}

Fasting blood glucose levels were measured using an Accu-Chek glucose meter (Roche, Indianapolis, IN, USA). For intraperitoneal glucose tolerance test (IPGTT), mice were fasted for 16 hours and injected with glucose $(2 \mathrm{~g} / \mathrm{kg})$. Blood glucose levels were measured at 15, 30, 60 and 120 minutes after injection. Insulin levels from cultured cells or total pancreas were determined with an insulin ELISA kit (Alpco, Salem, NH, USA). Plasma glucagon levels were determined with a glucagon RIA kit (Millipore, Billerica, MA, USA), following the manufacturer's instructions.

\section{Western blot}

Protein was extracted from the cultured cells by RIPA buffer (Sigma-Aldrich) for Western Blot. The supernatants were collected after centrifugation at $12000 \times \mathrm{g}$ at $4^{\circ} \mathrm{C}$ for $20 \mathrm{~min}$. Protein concentration was determined using BCA protein assay, and whole lysates were mixed with $4 \times$ SDS loading buffer $(125 \mathrm{mmol} / \mathrm{l}$ Tris-HCl, 4\% SDS, $20 \%$ glycerol, $100 \mathrm{mmol} / \mathrm{l}$ DTT, and $0.2 \%$ bromophenol blue) at a ratio of $1: 3$. Samples were heated at $100{ }^{\circ} \mathrm{C}$ for $5 \mathrm{~min}$ and were separated on SDS-polyacrylamide gels. The separated proteins were then transferred to a PVDF membrane. The membrane blots were first probed with a primary antibody. After incubation with horseradish peroxidase-conjugated second antibody, autoradiograms were prepared using the enhanced chemiluminescent system to visualize the protein antigen. The signals were recorded using X-ray film. Primary antibodies for Western Blot are anti-Pax4 (Santa Cruz Biotechnology) and anti$\beta$-actin (Cell Signaling, San Jose, CA, USA). Secondary antibody is HRP-conjugated anti-rabbit (Jackson ImmunoResearch Labs). Images shown in the figure were representative from 5 repeats.

\section{Statistics}

All values are depicted as mean \pm standard error and are considered significant if $p<0.05$. All data were statistically analysed using one-way ANOVA with a Bonferoni correction, followed by Fisher's exact test to compare 2 groups. 
A

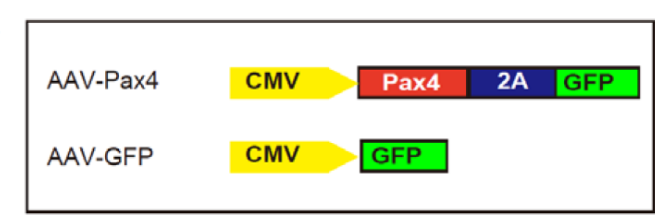

C
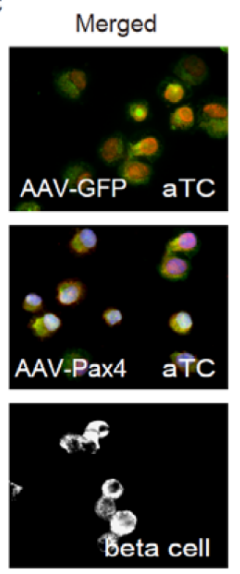

D
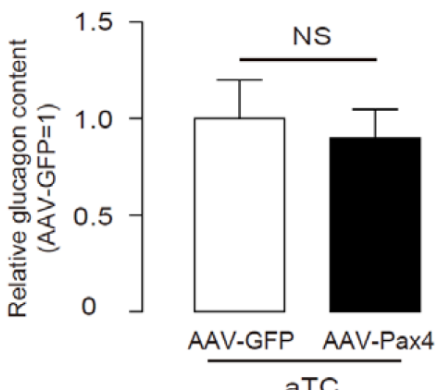

B

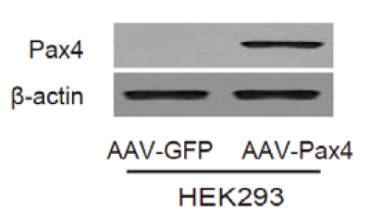

Pax4
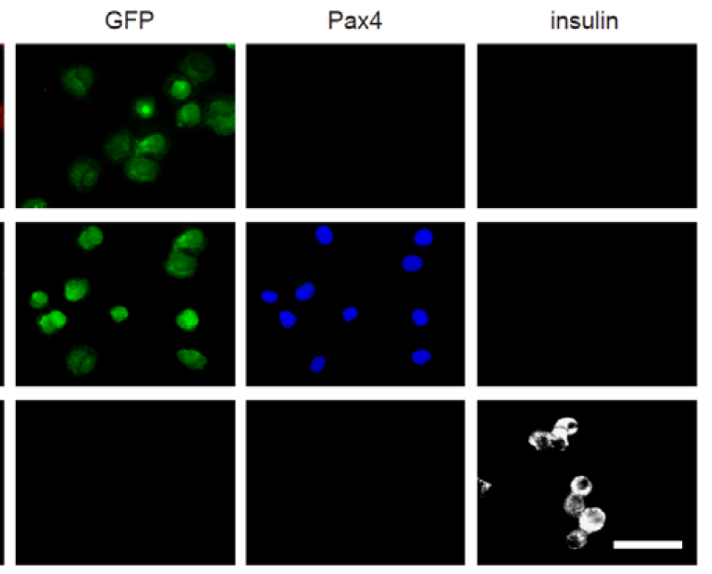

E

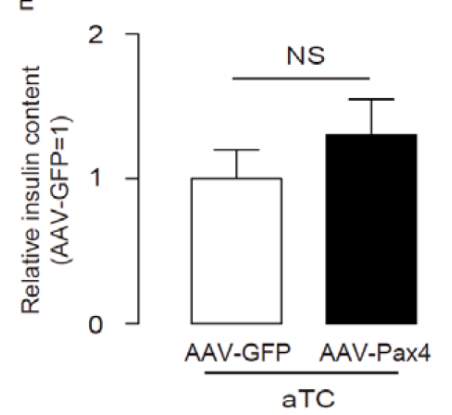

Fig. 1. Overexpression of Pax4 in vitro did not transduce alpha cells into beta cells. (A) We generated AAV vectors that carry Pax4 and GFP, AAV-CMV-Pax4-2A-GFP (simplified as AAV-Pax4). AAV-CMV-GFP (simplified as AAV-GFP) was used as a control. (B) The overexpression of Pax4 by AAV-Pax4 in cells was confirmed by Western blot, using HEK293 cells. (C) Immunostaining for Pax4, insulin, glucagon and GFP in AAV-Pax4 or AAV-GFP transduced aTC cells. Beta cells were used as a control for insulin. (D) ELISA for glucagon content. (E) ELISA for insulin content. *: Scale bar is $20 \mu \mathrm{m}$. NS: non-significant. $\mathrm{n}=5$. Statistic: one-way ANOVA with a Bonferoni correction, followed by Fisher's exact test to compare 2 groups.

\section{Results}

Generation of Pax4-expressing AAV vectors

First, we generated AAV vectors that carry Pax4 and GFP, AAV-CMV-Pax4-2A-GFP (simplified as AAV-Pax4). AAV-CMV-GFP (simplified as AAV-GFP) was used as a control (Fig. 1A). The overexpression of Pax4 by AAV-Pax4 in cells was confirmed by Western blot (Fig. 1B).

Overexpression of Pax4 in vitro did not transduce alpha cells into beta cells

To examine the effects of overexpression of Pax 4 on alpha cells, we transduced aTC cells by AAV-Pax4 or AAV-GFP in vitro. We found that overexpression of Pax4 in aTC cells did not inhibit glucagon expression by immunostaining (Fig. 1C), and by ELISA on glucagon content (Fig. 1D). Moreover, Pax4 in aTC cells did not induce insulin expression, by immunostaining 
A

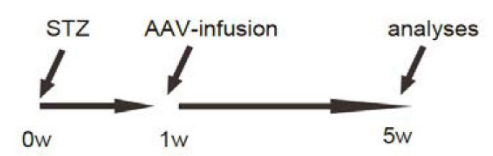

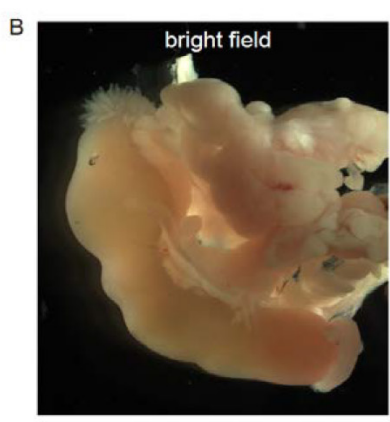

AAV-GFP $1 \mathrm{~W}$

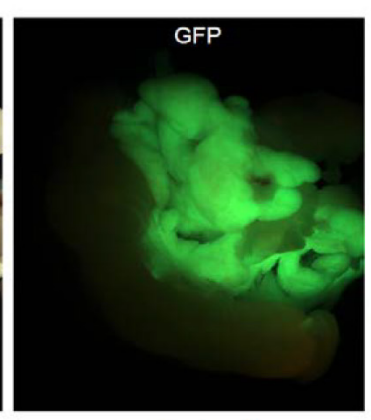

AAV-GFP 1w

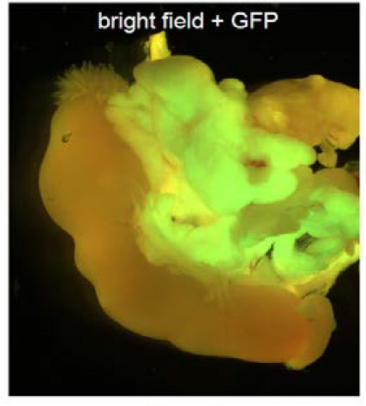

AAV-GFP $1 \mathrm{w}$

Fig. 2. Efficient gene delivery into mouse pancreas. (A) Schematic of the model. STZ was given to mice to destroy beta cells. One week later, AAVs were intraductally infused to the mice. After another 4 weeks, the mice were sacrificed for analyses. (B) Representative gross images of the mice after AAV-GFP infusion.

Fig. 3. Overexpression of Pax4 in vivo did not alter blood glucose control. (A) The fasting blood glucose of STZ-treated mice. (B) The glucose responses (IPGTT) of STZ-treated mice. NS: non-significant. $\mathrm{n}=5$. Statistic: one-way ANOVA with a Bonferoni correction, followed by Fisher's exact test to compare 2 groups.

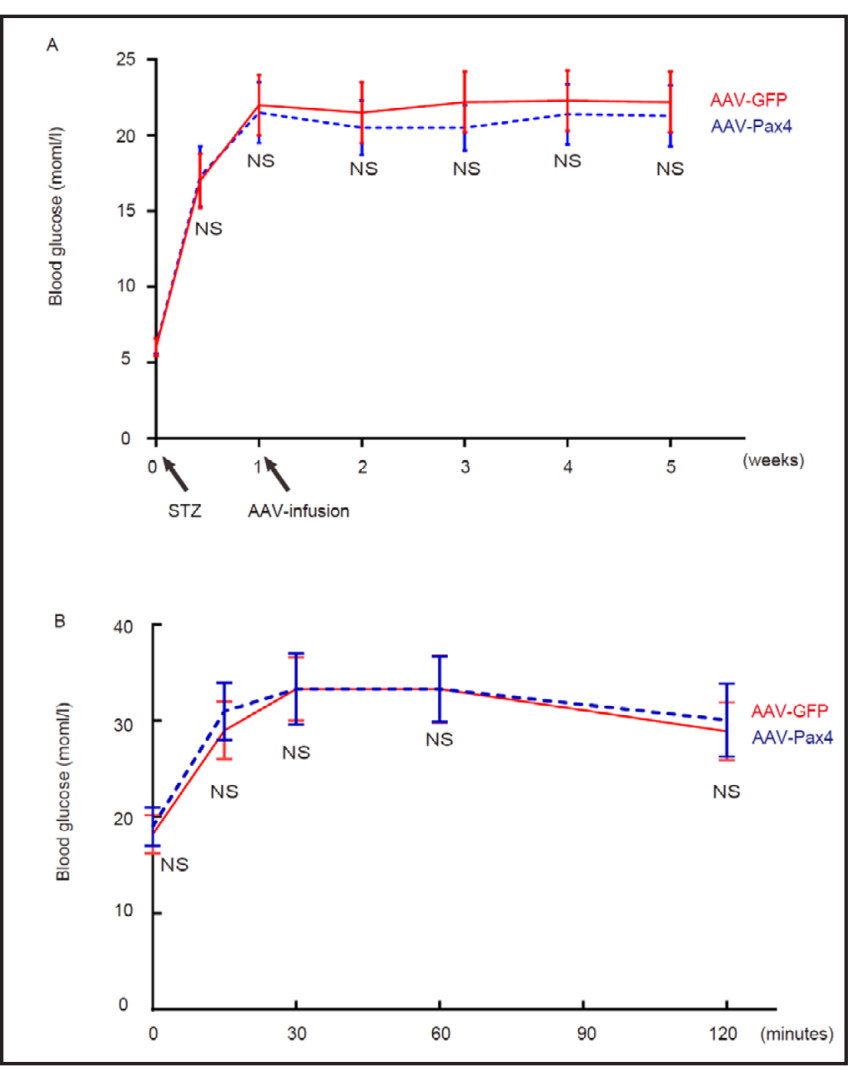

(Fig. 1C), and by ELISA on insulin content (Fig. 1E). Together, these data suggest that Overexpression of Pax4 in vitro did not transduce alpha cells into beta cells.

Overexpression of Pax4 in vivo did not transduce alpha cells into beta cells

To examine the effects of overexpression of Pax4 on primary alpha cells in vivo, we used a recently published intraductal infusion technology [25, 26] to overexpress Pax4 in the pancreas. Since beta cell destruction by toxin may not only increase alpha cell number, but also create a hyperglycemic environment, we also used a beta-cell toxin streptozotocin (STZ) to kill majority of beta cells before viral infusion (Fig. 2A).

\section{KARGER}


Fig. 4. Overexpression of Pax4 in vivo did not increase beta cells. (A) The overexpression of Pax4 in the target cells was confirmed by Western blot, using isolated mouse cells. (B) Immunstaining staining for insulin, glucagon and GFP in the STZ-treated AAV-Pax4-infused mouse pancreas at analysis, shown by a representative image. *: Scale bar is $20 \mu \mathrm{m}$.
Fig. 5. Overexpression of Pax4 in vivo did not increase beta-cell mass or pancreas insulin. (A) Beta-cell mass. (B) Pancreas insulin content. NS: non-significant. $\mathrm{n}=5$. Statistic: one-way ANOVA with a Bonferoni correction, followed by Fisher's exact test to compare 2 groups.
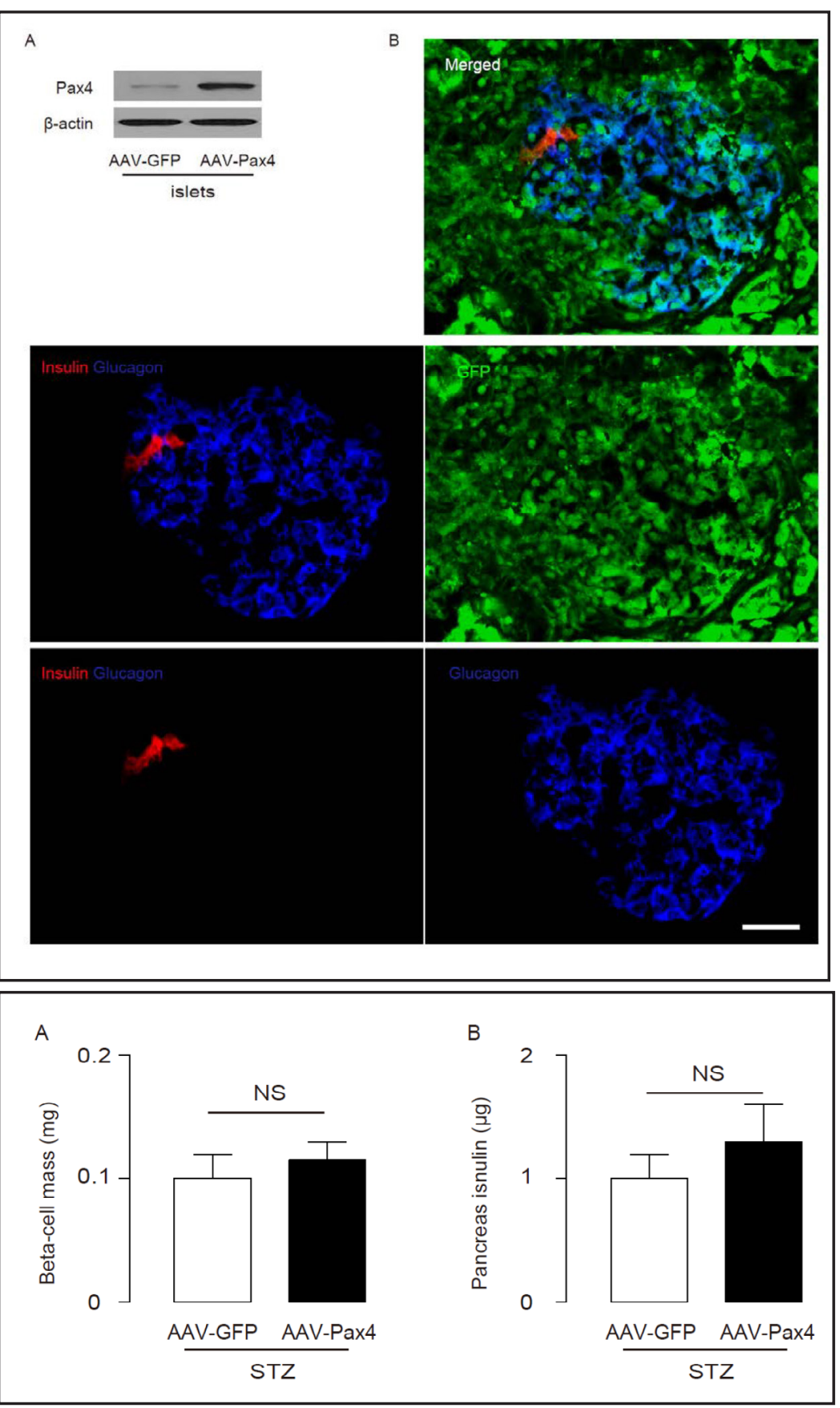

The quality of viral infusion was manifested by gross imaging, which show rather even distribution of GFP signals due to the presence of GFP in the viral construct (Fig. 2B).

We found that the AAV-Pax4 infusion neither decreased the fasting blood glucose of STZtreated mice (Fig. 3A), nor altered the glucose responses in these mice (Fig. 3B), compared to the control AAV-GFP-infused mice. However, AAV-Pax4 infusion indeed increased Pax4 levels in the mouse islets (Fig. 4A).

Then, we examined the histology of the pancreas, and found no increases in beta cell number, shown by immunohistochemistry (Fig. 4B), and by analyses of beta-cell mass (Fig. $5 \mathrm{~A}$ ), or pancreas insulin content (Fig. 5B). Together, these data suggest that Overexpression of Pax4 in vivo did not transduce alpha cells into beta cells.

\section{KARGER}




\section{Discussion}

The treatment of diabetes is one of the greatest medical challenges in this century. Diabetes results from a deficiency or functional impairment of insulin-producing beta cells, which may presents alone or in combination with insulin resistance [6-12]. The replacement or regeneration of functional beta cells should reverse the progression of diabetes [6-12]. Therefore, this concept has prompted great efforts to create new beta cells through transdifferentiation or reprogramming of non-beta cells into beta cells or to induce proliferation of beta cells [6-12]. However, this latter approach has been shown to be extremely difficult, since beta cells are generally post-mitogenic [13-18]. On the other hand, forming functional beta cells from non-beta cells, although attractive, has been shown to be barely possible without genetic approaches.

Pancreatic alpha cells are one of the major islet endocrine cells in the pancreas. Developmentally, alpha cells are closely related to beta cells [27]. Moreover, previous studies have provided evidence that may support a possibility that alpha cells have a potential to be reprogrammed into beta cells under certain circumstances [20, 21, 27]. Recently, embryonic expression of a key transcription factor Pax4 in endocrine progenitors or newly formed alpha cells has been shown to induce formation of beta cells from alpha cells [19]. However, whether this approach may trigger the reprogramming of adult or mature alpha cells is unknown. Indeed, it has been shown that expression of a transcription factor in either newly formed alpha cells or adult alpha cells may be very different $[27,28]$. Thus, there is a need to examine whether Pax4 is sufficient to trigger alpha-to-beta cell reprogramming in adult alpha cells.

Here, we generated an AAV carrying Pax4 and GFP under a CMV promoter, since a previous study has shown that CAG promoter is not optimal for transduction of alpha cells [25]. We successfully transduced mouse alpha cells both in vitro and in vivo, using an intraductal infusion technology for the latter approach. This technique has been recently published and has been shown to be an efficient gene delivery method into pancreas [25, 26], which was further confirmed in the current study in that we found that the infection efficiency for endocrine cells and acinar cells are greater than $90 \%$, while duct cells were rarely infected. However, we found no evidence of alpha-to-beta reprogramming by Pax 4 overexpression both in vitro and in vivo, suggesting that Pax4 is not sufficient to trigger alpha-to-beta cell reprogramming in adult alpha cells.

Thus, overexpression of Pax 4 in alpha cells may not increase functional beta cells in diabetic patients. Additional transcription factors may be needed to initiate such a reprogramming.

\section{Disclosure Statement}

None disclosed.

\section{Acknowledgement}

This work was supported by Liaoning Province Natural Science Fund Program (NO: 2013022069).

\section{Reference}

1 Weir GC, Bonner-Weir S: Islets of langerhans: The puzzle of intraislet interactions and their relevance to diabetes. J Clin Invest 1990;85:983-987.

2 Matveyenko AV, Butler PC: Relationship between beta-cell mass and diabetes onset. Diabetes Obes Metab 2008;10:S23-31.

3 Murtaugh LC, Melton DA: Genes, signals, and lineages in pancreas development. Annu Rev Cell Dev Biol 2003;19:71-89. 


\section{Cellular Physiology Cell Physiol Biochem 2015;36:1735-1742

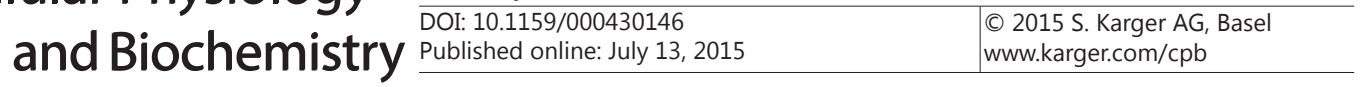 \\ Chen et al.: Pax4 Fails to Transduce Alpha to Beta Cells}

4 Zaret KS, Grompe M: Generation and regeneration of cells of the liver and pancreas. Science 2008;322:1490-1494.

5 Edlund H: Pancreatic organogenesis--developmental mechanisms and implications for therapy. Nat Rev Genet 2002;3:524-532.

-6 Dor Y, Brown J, Martinez OI, Melton DA: Adult pancreatic beta-cells are formed by self-duplication rather than stem-cell differentiation. Nature 2004;429:41-46.

7 Teta M, Rankin MM, Long SY, Stein GM, Kushner JA: Growth and regeneration of adult beta cells does not involve specialized progenitors. Dev Cell 2007;12:817-826.

8 Meier JJ, Butler AE, Saisho Y, Monchamp T, Galasso R, Bhushan A, Rizza RA, Butler PC: Beta-cell replication is the primary mechanism subserving the postnatal expansion of beta-cell mass in humans. Diabetes 2008;57:1584-1594.

-9 Georgia S, Bhushan A: Beta cell replication is the primary mechanism for maintaining postnatal beta cell mass. J Clin Invest 2004;114:963-968.

10 Xiao X, Chen Z, Shiota C, Prasadan K, Guo P, El-Gohary Y, Paredes J, Welsh C, Wiersch J, Gittes GK: No evidence for beta cell neogenesis in murine adult pancreas. J Clin Invest 2013;123:2207-2217.

-11 Johansson M, Mattsson G, Andersson A, Jansson L, Carlsson PO: Islet endothelial cells and pancreatic betacell proliferation: Studies in vitro and during pregnancy in adult rats. Endocrinology 2006;147:2315-2324.

12 Butler AE, Cao-Minh L, Galasso R, Rizza RA, Corradin A, Cobelli C, Butler PC: Adaptive changes in pancreatic beta cell fractional area and beta cell turnover in human pregnancy. Diabetologia 2010;53:2167-2176.

13 Gunasekaran U, Gannon M: Type 2 diabetes and the aging pancreatic beta cell. Aging 2011;3:565-575.

14 Kushner JA: The role of aging upon beta cell turnover. J Clin Invest 2013;123:990-995.

15 Rankin MM, Kushner JA: Adaptive beta-cell proliferation is severely restricted with advanced age. Diabetes 2009;58:1365-1372.

-16 Teta M, Long SY, Wartschow LM, Rankin MM, Kushner JA: Very slow turnover of beta-cells in aged adult mice. Diabetes 2005;54:2557-2567.

17 Stolovich-Rain M, Hija A, Grimsby J, Glaser B, Dor Y: Pancreatic beta cells in very old mice retain capacity for compensatory proliferation. J Biol Chem 2012;287:27407-27414.

18 Salpeter SJ, Khalaileh A, Weinberg-Corem N, Ziv O, Glaser B, Dor Y: Systemic regulation of the age-related decline of pancreatic beta-cell replication. Diabetes 2013;62:2843-2848.

19 Collombat P, Xu X, Ravassard P, Sosa-Pineda B, Dussaud S, Billestrup N, Madsen OD, Serup P, Heimberg H, Mansouri A: The ectopic expression of pax4 in the mouse pancreas converts progenitor cells into alpha and subsequently beta cells. Cell 2009;138:449-462.

20 Thorel F, Nepote V, Avril I, Kohno K, Desgraz R, Chera S, Herrera PL: Conversion of adult pancreatic alphacells to beta-cells after extreme beta-cell loss. Nature 2010;464:1149-1154.

21 Chung CH, Hao E, Piran R, Keinan E, Levine F: Pancreatic beta-cell neogenesis by direct conversion from mature alpha-cells. Stem Cells 2010;28:1630-1638.

22 Khan IF, Hirata RK, Russell DW: Aav-mediated gene targeting methods for human cells. Nat Protoc 2011;6:482-501.

-23 Hajitou A, Rangel R, Trepel M, Soghomonyan S, Gelovani JG, Alauddin MM, Pasqualini R, Arap W: Design and construction of targeted aavp vectors for mammalian cell transduction. Nat Protoc 2007;2:523-531.

24 Grieger JC, Choi VW, Samulski RJ: Production and characterization of adeno-associated viral vectors. Nat Protoc 2006;1:1412-1428.

25 Jimenez V, Ayuso E, Mallol C, Agudo J, Casellas A, Obach M, Munoz S, Salavert A, Bosch F: In vivo genetic engineering of murine pancreatic beta cells mediated by single-stranded adeno-associated viral vectors of serotypes 6, 8 and 9. Diabetologia 2011;54:1075-1086.

26 Xiao X, Guo P, Prasadan K, Shiota C, Peirish L, Fischbach S, Song Z, Gaffar I, Wiersch J, El-Gohary Y, Husain SZ, Gittes GK: Pancreatic cell tracing, lineage tagging and targeted genetic manipulations in multiple cell types using pancreatic ductal infusion of adeno-associated viral vectors and/or cell-tagging dyes. Nat Protoc 2014;9:2719-2724.

27 Yang YP, Thorel F, Boyer DF, Herrera PL, Wright CV: Context-specific alpha- to-beta-cell reprogramming by forced pdx1 expression. Genes Dev 2011;25:1680-1685.

28 Shamsi F, Parlato R, Collombat P, Mansouri A: A genetic mouse model for progressive ablation and regeneration of insulin producing beta-cells. Cell Cycle 2014;13:3948-3957. 